\title{
Modelling of Tsunami Forces on Coastal Structures: a Review
}

\author{
N. Govindasamy ${ }^{1 *}$, N.H. Mardi ${ }^{2}$, M.A. Malek ${ }^{3}$ \\ ${ }^{1}$ Department of Civil Engineering, College of Engineering, Universiti Tenaga Nasional \\ ${ }^{2,3}$ Institute of Power Energy (IPE), Universiti Tenaga Nasional \\ *Corresponding author E-mail: nelvindran@gmail.com
}

\begin{abstract}
This paper reviews methods applicable to assess the impact of tsunami forces on coastal structures. Countries affected by tsunamis have proven that this environmental disaster has costed billions of losses, such as the event occurred during year 2004 Andaman tsunami. Therefore, there is a need to assess the structural behaviour upon the impact of tsunami forces in order to minimize the damages and to ensure that coastal structures are able to sustain loading from high current-velocity waves. Currently in practice, there are two approaches of accessing the impacts of tsunami on structures namely physical modelling and experiment or numerical modelling and simulation. Numerical modelling methods are expected to produce acceptable analysis on the stability and condition of structures subjected to tsunami loadings since it incorporates several important parameters which are not implemented in physical modelling. The result from this study is expected to prompt engineers and relevant authorities to revise the current design guidelines on coastal structures which could sustain possible tsunami event in the future.
\end{abstract}

Keywords: Modelling; Numerical Model; Physical Model; Coastal Structure; Tsunami

\section{Introduction}

The 26 December 2004 Andaman tsunami event was regarded as one of the most catastrophic natural disaster to occur in the Asian region. It resulted to the death of about a quarter million people worldwide. The tsunami claimed more than 220000 lives and wrecked the shelter of 800000 people in total. The total economic cost of the catastrophe is estimated to worth more than 10 billion Euros and is significantly damaging to the victimized countries. It is well understood that earthquakes and tsunamis are actions of nature which are inevitable; however, it is possible to prepare for the possible occurrence of these dangerous waves in the coming years. The nature of tsunami forces should be given higher attention in order to mitigate such losses as suffered by the victims of the 2004 Andaman tsunami event.

In recent years, there has been a development and higher interest by engineers and scientist to investigate the possible occurrences of tsunami which may affect the coastal regions of the respective countries. Consecutively, focus has been shifted from the Andaman Sea to the South China Sea as the next possible tsunami source. This is because the Manila Trench, which is located along the South China Sea, was identified as a high-potential earthquake zone that may trigger a potential tsunami event [2][3]. Previous studies on tsunami event [4][5] in Malaysia focused on the Andaman tsunami. Thus, less study was conducted on tsunami source from South China Sea [6]. Furthermore, these tsunami studies primarily focused only on the behavior of these dangerous waves which include phases of generation, propagation, and run-up.

This review is significant since currently, not much attention focuses on the effects of these tsunami waves to existing structures located at the coastal areas. This raises concern to coastal communities in Malaysia especially at the east coast of Peninsular Malaysia which may be prone to tsunami disaster from South China Sea any time in the future. Hence, it is highly significant to choose a suitable method to analyze the coastal structures subjected to tsunami forces in order to prepare and minimize possible damages particularly at the east coast of Malaysia. This paper reviews method used by various researchers worldwide and provides insight for engineers and scientist to assess effects of tsunami forces to coastal structures. The findings are anticipated to improve the current design guidelines on coastal structures practice in Malaysia.

\section{Tsunami Forces and Building Codes}

The probability of tsunami occurrences is low, however, the damages caused during the last two tsunamis (year 2004 Indian Ocean tsunami and year 2011 Japan tsunami) have prompted scientists and engineers to consider elements of tsunami resilient in the design of coastal structures for the safety of coastal communities. At present, there are five design codes [7]-[11] and guidelines specifically accounted for tsunami-induced loads as listed in Table 1.

Table 1: Existing design codes and description

\begin{tabular}{|c|c|}
\hline Code & Description \\
\hline $\begin{array}{l}\text { Federal Emergency Man- } \\
\text { agement Agency (FEMA) } \\
55\end{array}$ & $\begin{array}{l}\text { The code is adopted by the Federal Emer- } \\
\text { gency Management Agency, the United } \\
\text { States, and recommends formulae for tsu- } \\
\text { nami-induced flood and wave loads. }\end{array}$ \\
\hline $\begin{array}{l}\text { City and County of Hono- } \\
\text { lulu Building Code }(\mathrm{CCH})\end{array}$ & $\begin{array}{l}\text { The code was developed by the Department } \\
\text { of Planning and Permitting of Honolulu, } \\
\text { Hawaii, United States makes provisions for } \\
\text { regulations that apply to districts located at } \\
\text { flood and tsunami-risk areas. }\end{array}$ \\
\hline $\begin{array}{l}\text { Structural Design Method } \\
\text { of Buildings for Tsunami }\end{array}$ & $\begin{array}{l}\text { This code was proposed by the Building } \\
\text { Center of Japan and outlines the structural }\end{array}$ \\
\hline
\end{tabular}




\begin{tabular}{|c|c|}
\hline Resistance (SMBTR) & design for tsunami refuge buildings. \\
\hline $\begin{array}{l}\text { Development of Guide- } \\
\text { lines for Structures that } \\
\text { Serve as Tsunami Vertical } \\
\text { Evacuation Sites }\end{array}$ & $\begin{array}{l}\text { The guidelines were prepared by Harry Yeh, } \\
\text { to estimate tsunami -induced forces on struc- } \\
\text { tures for Washington State Department of } \\
\text { Natural Resources. }\end{array}$ \\
\hline $\begin{array}{l}\text { American Society of Civil } \\
\text { Engineers (ASCE) 7-16 }\end{array}$ & $\begin{array}{l}\text { The tsunami loads and effects chapter were } \\
\text { proposed by ASCE in } 2016 \text { and is applicable } \\
\text { only to the states of Alaska, Washington, } \\
\text { Oregon, California, and Hawaii, which are } \\
\text { areas that is susceptible and prone to tsunami } \\
\text { hazards. }\end{array}$ \\
\hline
\end{tabular}

These design codes include various loads namely: (i) hydrostatic force (ii) buoyant force (iii) hydrodynamic force (iv) surge force (v) debris impact force and (vi) wave- breaking force. The application of these forces is illustrated in Fig.1. It has to be highlighted that the important parameters for the tsunami load applications are direction of flow, inundated depth, and the velocity of wave flow. Several tsunami scenarios that varies in terms of magnitude and direction can help to predict and measure the extent and limit of the coastal inundation due to tsunami event. This includes modelling of coastal inundation areas by numerical simulation. However, the flow velocity and direction of these dangerous waves are generally more complex and difficult to estimate. The estimation of flow velocities is difficult to predict as it can reach an extremely high value which may differ in terms of magnitude. Meanwhile, the topographic characteristics onshore as well as type of soil, and obstacles in the inundation zones may significantly affect the direction of flow. However, the investigation of these features is not the scope of this study.

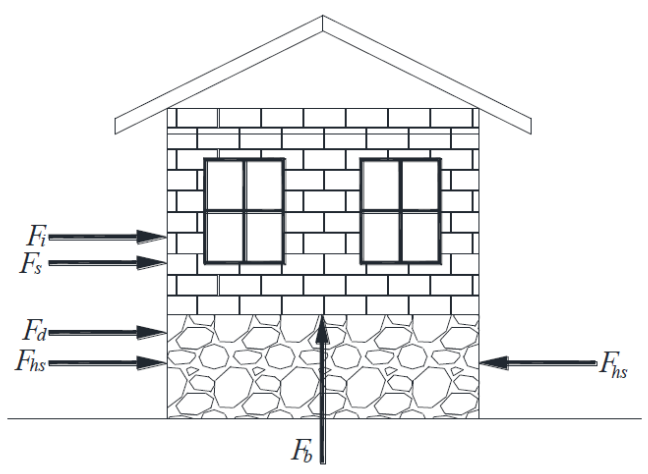

Fig. 1: Illustration of tsunami forces on a coastal structure

\subsection{Physical Modelling and Experiment}

The applications of tsunami forces on structures are thoroughly investigated in the past through physical modelling and experimental-based research. An experimental research was conducted to test the effect of tsunami forces on a storage tank, whereby two conditions were considered which are with and without surrounding tanks [13]. A wave basin with dimension of $30 \mathrm{~m}$ in length, $19 \mathrm{~m}$ of width, and a depth of $1.5 \mathrm{~m}$ was used in the experimental study. The wave basin generates a tsunami wave similar to a solitary wave which eventually will flow and hit the cylindrical tank as a fluid force on the structure. The tsunami forces are considered as vertical and horizontal components acting on the cylindrical component structure. As a result, it was found that the highest tsunami wave load was experienced by the object surrounded by storage tanks in comparison to without surrounding storage tanks. The large distance between the cylindrical-shaped storage tanks was the variable that affected the findings.

Another experimental study [14] was conducted to investigate the interaction of tsunami force with an onshore structure. An experimental study in the laboratory was initiated specifically to study impact of tsunami force on a square-shaped prism model. The study involved different orientations of the square prism to the flow direction. In this case, the square prism acts as the structure of interest whereby a tsunami wave was produced through $1.2 \mathrm{~m}$ wide and $0.8 \mathrm{~m}$ deep wave flume equipped with an automatic gate designed to generate tsunami scenario. Hence, it was concluded that the force distribution is subjected to the structure orientation with respect to direction of flow which was varied in the experimental investigation. It was concluded that the pressure distribution depended on the orientation of the structure with respect to flow direction varied throughout the experiment. In addition, it was found that the tsunami bore velocity has higher significant effect on the tsunami force rather than the wave height.

Coastal structures that are affected by tsunami forces at inundation phase are mainly due to the unstable sea water flow around the specified structure. The phenomenon may be assessed as a combination of several tsunami forces such as drag force, inertia force, and hydrostatic force. Hence, an experimental research was conducted to investigate the effects of unsteady flow on rectangular buildings, whereby the unstable flows are primarily due to troughled (N-waves) as well as solitary waves [15]. Here, the tsunami wave generator is a low-pressure head pump which is directly connected to a plenum chamber that is immersed partially. Based on findings obtained from the experiment, it was discovered that the height of water reaches about $10-90 \%$ of the obstacle height. Therefore, it is concluded that the high measurement of water at the face of obstacles is proportional to the blocking fractions.

Laboratory experiments were also carried out to reveal the damaged mechanism of a bridge girder by assessing the exerted tsunami forces [16]. The particular tsunami scenario was produced based on a dam break model at $17.5 \mathrm{~m}$ long, $0.45 \mathrm{~m}$ high and 0.6 $\mathrm{m}$ wide with a wave tank that has two parts. The upstream part served as the reservoir to generate tsunami, while the downstream part was used to simulate tsunami propagation and tsunami forces on the bridge structures. The results proved that the measured forces for the broken waves were larger than those of the unbroken waves. Larger wave heights reached the value of peak force more rapidly than those of smaller wave heights.

Tsunami forces on structures were further investigated by experiment using wave tank. The model tsunami wave was created by dropping a rectangular block into the water at the deepest end of the tank [17]. The sudden displacement of water at the deep end of the tank created a wave that propagated to the shore where the model houses were placed, as the structure of interest in the experiment. The maximum pressure at the front wall of the house was $5.1 \mathrm{kPa}$ which corresponds to $127.5 \mathrm{kPa}$ based on Froude scaling $(5.1 \times 25)$ for a full-sized house with tsunami wave velocity of $5 \mathrm{~m} / \mathrm{s}$.

Various wave conditions similar to a tsunami event were tested with a large-scale physical model [18]. The purpose was to investigate the effects of wave-induced vertical and horizontal force on an elevated coastal structure. The hypothesis from the study proved that both horizontal and vertical forces are directly proportional to the wave height.

\subsection{Numerical Modelling and Simulation}

Numerical modelling is generally used to assess impacts of tsunami forces on structures. It usually incorporates suitable hydrodynamic equations that are validated. It is typically used to analyse certain characteristics strength of a structure subjected to tsunami wave forces.

An investigation on the effects of tsunami forces to a vertical wall at different wave (tsunami) heights and cross-shore locations of vertical walls was conducted [19]. It was conducted by using the COBRAS numerical model which applies the Reynolds-averaged Navier-Stokes equation, k-epsilon turbulent closure, and volume of fluid method. The findings proved that the maximum tsunami force is directly proportional to the wave height. A similar study which applies the same equation was tested on a beachfront house [20]. Results suggested that the wave force, period of interaction, 
and the moment of overturning is at the highest value when the structure is partially submerged.

The structural impact on a typical tsunami evacuation building based on implication of tsunami forces was previously assessed [21]. Two scenarios of tsunami forces were applied on the structure which was the triangular and trapezoidal force distribution. The behaviour of the ten-storey and reinforced concrete (RC) structure was measured based on its peak force. The tsunami forces were also applied in two horizontal directions of the frame. A numerical investigation of submerged horizontal cylinders subjected to tsunami forces was also carried out. Coastal and offshore structures are commonly designed with cylindrical structural components which prompted the case for this study [22]. The turbulent model was adopted using the classic Smagorinsky model (1963). The numerical simulation proved that the high maximum wave load and maximum hydrodynamic load is mainly produced by waves similar to a tsunami wave in compared to a solitary wave which explained the gradual increase in rate.

The most recent practical numerical assessment was adopted by particle-based model coupling with Smoothed Particle Hydrodynamics (SPH), Discrete Element Method (DEM) and Extended DEM (EDEM). The study involved computing the interaction of the structure with fluid forces. The structure of interest was a tsunami shelter with an elastic mooring which is directly impacted by a floating debris [23]. A common practice in numerical model is by adopting Navier-Stokes equations which is the same case in this research. Based on the simulation, the tsunami pressure and its shelter motions can be reduced by designing a shelter that is trapezoidal and streamline in shape.

A numerical assessment study of tsunami disaster on rubble mound breakwater at Haydarpasa Port, Turkey was carried out to assess the stability and failure mechanism of breakwater [24]. The numerical model used was OpenFOAM which adopted the Volume-Averaged Reynolds-Averaged Navier-Stokes solver. It is found that forces acting on single stone located behind the crownwall at the rear side of breakwater are at critical stability. In addition, the same numerical model was utilized to analyse the effect of tsunami-induced forces on a bridge superstructure, whereby it was concluded that the tsunami waves effects one corner of the bridge first [25]. Thus, this impact will create a decline in maximum force upon the impact of the waves which will produce a counter-clockwise moment that will eventually lift up a corner of the bridge.

Besides that, a tsunami inundation in Seaside, Oregon was modelled based on a 3D computational fluid dynamics (CFD). The inundation was then narrowed down to investigate the tsunami forces on several structures affected upon inundation in a coastal community [26]. The structures experienced a significantly large horizontal and vertical forces which may eventually damage the buildings due to local failure. This further proves the severity of the tsunami forces when it impacts a certain structure along its path. CFD was also used as part of a numerical simulation to compare different condition of wave forces with experimental data [27]. It was found that mesh size is not significantly sensitive for horizontal and vertical forces. Hence, estimation of tsunami forces can still be reliable by using bigger mesh size and concurrently save cost at the same time.

Two-dimensional (2D) numerical modelling are also applied in tsunami analysis [28]-[29], whereby a specific site in Westport, Washington was a subject of hazard classification due to a tsunami event. It has to be highlighted that 2D models can typically model the entire inundation area at much less computational cost, and can predict tsunami forces on structures as well when combined with some empirical formulas designed from the past. In current practice, the $3 \mathrm{D}$ numerical models that solves NavierStokes equations are typically too expensive to model the entire inundation region and to predict tsunami forces on structures. Most 3D numerical models thus include only single structure in contrast to 2D models which can include an entire area and several type of structures. The comparison between 2D and 3D modelling is justified previously [30].

\section{Discussion}

There are ten different methods of analysis and studies on the effects of tsunami to coastal structures presented in this study. These studies were summarized in Table 1 based on its modelling technique, type of structure, and outcomes. Based on the reviews carried out, all the methods and technique used are applicable to assess the severity of tsunami forces on coastal structures. However, it must be noted that all the experiments and simulations considered and assumed different parameters for various tsunami scenarios. The question still remains as to which method practically applies the actual tsunami event since there are several assumptions being made in terms of wave's behavior, boundary conditions, and topography.

Nevertheless, method by Petrone et.al [21] is most suitable to analyze structure subjected to tsunami loading. In this study, a load sensitivity analysis was conducted in order to assess the most significant application of tsunami force on the modelled structure. It was found that the distribution of the tsunami load has to be applied throughout the height of the structure and in this case, five point-loads was applied to each level of the building. Furthermore, the method used by Petrone et.al [21] modelled a structure which is an ideal tsunami evacuation building, designed according to both earthquake and tsunami actions. Unlike other methods, the reinforced concrete (RC) structure used in this study was a typical building that reflected a real-life application that has similar dimensions and design. This will give a clearer indication on the actual effects of tsunami forces as failure mechanism of a structure which depends on its design and dimension.

In addition, Petrone et.al [21] considered the tsunami wave loading as rectangular and trapezoidal loads which act on the columns of the structure. The tsunami wave behavior is uncertain due to effects such as onshore topography, roughness and wave period. Hence, considering the tsunami wave acting at different distributed load pattern is a better application method to be used in the analysis of structure. The method performed by other researchers in numerical simulation typically considers the tsunami force as a single point load acting on the structure which does not illustrate the actual tsunami wave's behavior. However, the hydrodynamic equations used in their simulation are still a good representation of tsunami waves. Meanwhile, physical modelling is mostly preferred by earlier researchers. Physical modelling provides a clearer view on impacts of tsunami waves to the identified structure since the model was set-up in a laboratory and the waves were produced through a wave tank or wave-maker. Despite of that, there are questions being raised as to whether physical modelling provides the correct results of tsunami event since there are many other parameters and conditions that are not being considered in the experiment such as roughness, friction, Manning's coefficient, and topography of the structure's location. Besides that, the wave velocity produced during the experiments may not reflect the actual rigorous velocity that may hit the structures when tsunami waves inundate the coastal areas. Last but not least, numerical modelling is capable of producing various range of tsunami magnitude and scenarios that provides better implications of tsunami event. While physical modelling focuses mainly on worst-case scenarios particularly the experience at Tohoku year 2011.

Table 2: Summary on effects of tsunami to structures

\begin{tabular}{|l|l|l|l|}
\hline $\begin{array}{l}\text { Author } \\
\text { (Year) }\end{array}$ & $\begin{array}{l}\text { Modelling } \\
\text { Technique }\end{array}$ & $\begin{array}{l}\text { Structure of } \\
\text { Interest }\end{array}$ & Findings \\
\hline $\begin{array}{l}\text { Araki et.al. } \\
(2017)\end{array}$ & Physical & Storage tank & $\begin{array}{l}\text { The highest tsunami } \\
\text { wave load was experi- } \\
\text { enced by the object sur- } \\
\text { rounded by storage tanks } \\
\text { in comparison to without } \\
\text { surrounding storage }\end{array}$ \\
\hline
\end{tabular}




\begin{tabular}{|c|c|c|c|}
\hline & & & tanks. \\
\hline $\begin{array}{l}\text { Shafiei et.al. } \\
(2016)\end{array}$ & Physical & Square prism & $\begin{array}{l}\text { Tsunami wave pressure } \\
\text { distribution is subjected } \\
\text { to the direction of flow } \\
\text { with regards to the posi- } \\
\text { tion and orientation of } \\
\text { structure. }\end{array}$ \\
\hline $\begin{array}{l}\text { Foster et.al. } \\
(2017)\end{array}$ & Physical & $\begin{array}{l}\text { Rectangular } \\
\text { building }\end{array}$ & $\begin{array}{l}\text { Maximum hydrodynamic } \\
\text { load of tsunami wave has } \\
\text { a gradual increasing rate } \\
\text { in comparison with soli- } \\
\text { tary wave. }\end{array}$ \\
\hline $\begin{array}{l}\text { Rahman } \\
\text { et.al. (2014) }\end{array}$ & Physical & Bridge girder & $\begin{array}{l}\text { Waves reached the peak } \\
\text { force value more rapidly } \\
\text { for larger wave heights } \\
\text { than those of smaller } \\
\text { wave heights. }\end{array}$ \\
\hline $\begin{array}{l}\text { Thusyanthan } \\
\text { et.al (2008) }\end{array}$ & Physical & $\begin{array}{l}\text { Coastal hous- } \\
\text { es }\end{array}$ & $\begin{array}{l}\text { Maximum pressure on } \\
\text { the front wall of the } \\
\text { house was } 5.1 \mathrm{kPa} \text { with } \\
\text { velocity of } 5 \mathrm{~m} / \mathrm{s}\end{array}$ \\
\hline $\begin{array}{ll}\text { Cho et.al. } \\
(2017)\end{array}$ & Numerical & Vertical wall & $\begin{array}{l}\text { Maximum tsunami force } \\
\text { is directly proportional to } \\
\text { the wave height. }\end{array}$ \\
\hline $\begin{array}{l}\text { Petrone et.al. } \\
(2017)\end{array}$ & Numerical & $\begin{array}{l}\text { Reinforced- } \\
\text { concrete (RC) } \\
\text { building }\end{array}$ & $\begin{array}{l}\text { The load sensitivity anal- } \\
\text { ysis highlighted that the } \\
\text { tsunami load has to be } \\
\text { applied throughout the } \\
\text { height of the structure, } \\
\text { whereby using a trape- } \\
\text { zoidal and triangular } \\
\text { pattern. }\end{array}$ \\
\hline $\begin{array}{ll}\text { Qu } & \text { et.al. } \\
(2017) & \end{array}$ & Numerical & $\begin{array}{l}\text { Horizontal } \\
\text { cylinder }\end{array}$ & $\begin{array}{l}\text { Maximum hydrodynamic } \\
\text { load of tsunami wave has } \\
\text { a higher rate of increase } \\
\text { in contrast to the solitary } \\
\text { wave. }\end{array}$ \\
\hline $\begin{array}{l}\text { Ardianti } \\
\text { et.al. (2018) }\end{array}$ & Numerical & $\begin{array}{l}\text { Tsunami } \\
\text { shelter with } \\
\text { mooring }\end{array}$ & $\begin{array}{l}\text { Trapezoidal and stream- } \\
\text { line tsunami shelter de- } \\
\text { sign can reduce tsunami } \\
\text { pressure and shelter } \\
\text { motion }\end{array}$ \\
\hline $\begin{array}{l}\text { Guler et.al. } \\
(2018)\end{array}$ & Numerical & $\begin{array}{l}\text { Rubble } \\
\text { mound } \\
\text { breakwater }\end{array}$ & $\begin{array}{l}\text { Tsunami forces acting on } \\
\text { the single stone located } \\
\text { behind the crown-wall at } \\
\text { the back side of the } \\
\text { breakwater causes a } \\
\text { critical stability. }\end{array}$ \\
\hline
\end{tabular}

\section{Conclusion}

This study highlighted the impacts of tsunami forces on various structures at different modelling techniques used to assess the severity of these tsunami waves. The most applicable technique is the numerical modelling technique that analyses both static and dynamic analysis. Physical modelling technique conveys only the worst-case tsunami scenario whereby numerical modelling is able to vary its tsunami event. This review paper will be able to assist engineers and scientist in selecting a suitable method to be used in assessing structures subjected to tsunami forces. It will assist in further improvements, incorporating tsunami forces in the current design guidelines of structures.

\section{Acknowledgement}

This study is funded by Tenaga Nasional Berhad Seeding Fund, Institute of Power Energy (IPE), Universiti Tenaga Nasional, Malaysia. Project code- U-TG-CR-18-03.

\section{References}

[1] S. Koshimura, S. Hayashi and H. Gokon, (2014), "The impact of the 2011 Tohoku earthquake tsunami disaster and implications to the reconstruction", Soils and Foundations, vol. 54, no. 4, pp. 560572 .

[2] Kirby, S., Geist, E., Lee, W.H., Scholl, D., Blakely, R. (2005), Tsunami source characterization for western Pacific subduction zones: a preliminary report. Report, USGS Tsunami Subduction Source Working Group.

[3] Y. Liu, A. Santos, S. Wang, Y. Shi, H. Liu and D. Yuen, (2007), "Tsunami hazards along Chinese coast from potential earthquakes in South China Sea", Physics of the Earth and Planetary Interiors, vol. 163, no. 1-4, pp. 233-244.

[4] H. Koh, S. Teh, P. Liu, A. Ismail and H. Lee, (2009). "Simulation of Andaman 2004 tsunami for assessing impact on Malaysia", Journal of Asian Earth Sciences, vol. 36, no. 1, pp. 74-83.

[5] S. Teh, H. Koh, P. Liu, A. Ismail and H. Lee, (2009) "Analytical and numerical simulation of tsunami mitigation by mangroves in Penang, Malaysia", Journal of Asian Earth Sciences, vol. 36, no. 1, pp. 38-46.

[6] N. Mardi, M. Malek and M. Liew, (2016), "Tsunami simulation due to seaquake at Manila Trench and Sulu Trench", Natural Hazards, vol. 85 , no. 3 , pp. $1723-1741$.

[7] FEMA 55 (2005). Coastal Construction Manual. Washington, USA: Federal Emergency Management Agency (FEMA).

[8] CCH (2000). City and County of Honolulu Building Code (CCH), Department of Planning and Permitting of Honolulu Hawaii, Article 11, Honolulu, Hawaii, 2000 [Chapter 16].

[9] Okada T, Sugano T, Ishikawa T, Ohgi T, Takai S, Hamabe C. (2005) Structural Design Method of Buildings for Tsunami Resistance (SMBTR).

[10] H. Yeh, I. Robertson and J. Preuss, (2005), Washington Dept. of Natural Resources Report No 2005-4.

[11] ASCE/SEI (ASCE/Structural Engineering Institute). (2016). "Minimum design loads for buildings and other structures." ASCE/SEI 7-16, Reston, VA.

[12] G. Chock, (2016) "Design for Tsunami Loads and Effects in the ASCE 7-16 Standard", Journal of Structural Engineering, vol. 142, no. 11 , p. 04016093

[13] S. Araki, W. Kunimatsu, S. Nishiyama, T. Furuse, S. Aoki and Y. Kotake, (2017), "Experimental study on tsunami wave load acting on storage tank in coastal area", Journal of Loss Prevention in the Process Industries, vol. 50, pp. 347-354.

[14] S. Shafiei, B. Melville and A. Shamseldin, (2016), "Experimental investigation of tsunami bore impact force and pressure on a square prism", Coastal Engineering, vol. 110, pp. 1-16.

[15] Foster, T. Rossetto and W. Allsop, (2017), "An experimentally validated approach for evaluating tsunami inundation forces on rectangular buildings", Coastal Engineering, vol. 128, pp. 44-57.

[16] S. Rahman, S. Akib and S. Shirazi, (2014), "Experimental investigation on the stability of bride girder against tsunami forces", Science China Technological Sciences, vol. 57, no. 10, pp. 2028-2036.

[17] N. Thusyanthan and S. Gopal Madabhushi, (2008), "Tsunami wave loading on coastal houses: a model approach", Proceedings of the Institution of Civil Engineers - Civil Engineering, vol. 161, no. 2, pp. 77-86.

[18] Park, H., Tomiczek, T., Cox, D. T., van de Lindt, J. W., \& Lomonaco, P. (2017). Experimental modeling of horizontal and vertical wave forces on an elevated coastal structure. Coastal Engineering, 128, 58-74.

[19] M. Cho, S. Shin, H. Yoon and D. Cox, (2017),"Numerical Simulation of Tsunami Force Acting on Vertical Walls", Journal of Coastal Research, vol. 79, pp. 289-293.

[20] Xiao, H., \& Huang, W. (2008). Numerical modeling of wave runup and forces on an idealized beachfront house. Ocean Engineering, 35(1), 106-116.

[21] C. Petrone, T. Rossetto and K. Goda, (2017), "Fragility assessment of a RC structure under tsunami actions via nonlinear static and dynamic analyses", Engineering Structures, vol. 136, pp. 36-53.

[22] K. Qu, X. Ren, S. Kraatz and E. Zhao, (2017), "Numerical analysis of tsunami-like wave impact on horizontal cylinders", Ocean Engineering, vol. 145, pp. 316-333.

[23] Ardianti, H. Mutsuda, K. Kawawaki and Y. Doi, (2018) "Fluid structure interactions between floating debris and tsunami shelter with elastic mooring caused by run-up tsunami", Coastal Engineering, vol. 137, pp. 120-132. 
[24] H. Guler, C. Baykal, T. Arikawa and A. Yalciner, (2018), "Numerical assessment of tsunami attack on a rubble mound breakwater using OpenFOAM ®", Applied Ocean Research, vol. 72, pp. 76-91.

[25] Motley, M. R., Wong, H. K., Qin, X., Winter, A. O., \& Eberhard, M. O. (2015). Tsunami-induced forces on skewed bridges. Journal of Waterway, Port, Coastal, and Ocean Engineering, 142(3), 04015025 .

[26] Qin, X., Motley, M. R., \& Marafi, N. (2018). Three-dimensional modeling of tsunami forces on coastal communities. Coastal Engineering.

[27] Park, H., Do, T., Tomiczek, T., Cox, D. T., \& van de Lindt, J. W. (2018). Numerical modeling of non-breaking, impulsive breaking, and broken wave interaction with elevated coastal structures: Laboratory validation and inter-model comparisons. Ocean Engineering, 158, 78-98.

[28] Ash, C. (2015) Design of a Tsunami Vertical Evacuation Refuge Structure in Westport, Washington. ASCE Structures Congress 2015

[29] González, F., LeVeque, R., \& Adams, L. (2013). Tsunami Hazard Assessment of the Ocosta School Site in Westport, WA

[30] Qin, X., Motley, M. R., LeVeque, R., Gonzalez, F., and Mueller, K. A comparison of a two-dimensional depth averaged flow model and a three-dimensional RANS model for predicting tsunami inundation and fluid forces 